\title{
Formulation and evaluation of buccal film of Ivabradine hydrochloride for the treatment of stable angina pectoris
}

\author{
Mohasin Lodhi, Akhilesh Dubey, Reema Narayan, Prabhakara Prabhu, Sneh Priya ${ }^{1}$ \\ Department of Pharmaceutics, Shree Devi College of Pharmacy, Kenjar Village, Mangalore, Karnataka, ${ }^{1}$ Department of Pharmaceutics, \\ NGSM Institute of Pharmaceutical Sciences, Mangalore, Karnataka, India
}

\section{Abstract}

Background: Ivabradine hydrochloride is an anti-anginal drug with a biological half-life of about 2 h, and repeated daily administration is needed to maintain effective plasma level. Present investigation of buccal films of Ivabradine hydrochloride is an attempt to avoid the repeated administration and release of drug in more controlled fashion, thereby, to improve the bioavailability. Materials and Methods: Buccal patches were fabricated by solvent casting technique and were evaluated for its physical properties like physical appearance, weight uniformity, thickness, swelling index, surface $\mathrm{pH}$, mucoadhesive time, and folding endurance, in vitro and ex vivo release studies. Results: A combination of hydroxypropyl methyl cellulose (HPMC) K15M and K100M with carbopol 940, PEG 6000 gave promising results. Further, the drug content of all the formulations was determined and was found to be uniform. All the formulations were subjected to in vitro release study using phosphate buffer $\mathrm{pH} 6.6$. Patches exhibited drug release in the range of $90.36 \% \pm 0.854$ to $98.37 \% \pm 0.589$ at the end of six hrs. The best formulations (F2 and F5) containing the composition of HPMC K15-37.50 mg, carbopol-0.42 mg, PEG6000-16.87 mg, Aspertane-0.28 mg, Tween-0.0023 mg and HPMC K100-37.50 mg, carbopol-0.42 mg, PEG6000-16.87 mg, Aspertane-0.28 mg, Tween-0.0023 mg respectively exhibited in vitro drug release of $97.61 \% \pm 0.589$ and $98.37 \% \pm 0.114$ respectively. The results of ex vivo diffusion using goat cheek pouch revealed that the drug release rate was retarded up to seven hrs. Films prepared with permeation enhancer (Tween 80) showed faster drug release. Finally, stability studies were carried out by using human saliva for the optimized formulation (F2-F5). Conclusion: The present study indicated enormous potential of mucoadhesive buccal patches containing Ivabradine for systemic delivery with an added advantage of circumventing hepatic first pass metabolism. Further work is recommended to support its efficacy claims by long term pharmacokinetic and pharmacodynamic studies in human beings.

Key words: Hydroxypropyl methyl cellulose K15 and K100, ivabradine hydrochloride, mucoadhesive buccal films, solvent casting.

\section{INTRODUCTION}

Amongst various routes of drug delivery, oral route is perhaps the most preferred route to the patient and the clinician alike. However, oral route presents some problems for few drugs. The

\section{Address for correspondence: \\ Mr. Akhilesh Dubey, \\ Department of Pharmaceutics, Shree Devi College of Pharmacy, \\ Mangalore, Karnataka - 574 142, India. \\ E-mail: akhilesh_intas@rediffmail.com}

\begin{tabular}{|l|l|}
\hline \multicolumn{2}{|c|}{ Access this article online } \\
\hline Quick Response Code: & Website: \\
\hline
\end{tabular}

enzymes in the GI fluids, GIT-pH conditions, and the enzymes bound to GIT membranes are the few factors responsible for the bioavailability problems. The blood that drains the GIT carries the drug directly to the liver leading to first-pass metabolism resulting in poor bioavailability. ${ }^{[1,2]}$ The inherent problems associated with the drug, in some cases, can be solved by modifying the formulation or by changing the routes of administration. Parenteral, mucosal, and transdermal routes circumvent hepatic first-pass metabolism and offer alternative routes for the systemic delivery of drugs. ${ }^{[3,4]}$ Buccal drug delivery system is an alternative method of systemic drug delivery that offers several advantages over both injectable and enterable methods. Mucoadhesive drug delivery systems utilize the property of bioadhesion of certain water soluble polymers, which become adhesive on hydration and hence can be used for targeting a drug to particular region like gastrointestinal tract, urogenital tract, ear, nose, and eye for an extended period of time. ${ }^{[5]}$

Ivabradine hydrochloride is a novel medication used for the symptomatic management of stable angina pectoris. Ivabradine 
acts by reducing the heart rate in a mechanism different from beta blockers and calcium channel blockers, two commonly prescribed anti-anginal drugs. It is classified as a cardiotonic agent. The plasma half-life is about $2 \mathrm{hrs}$, and bioavailibility is $40 \% .{ }^{[6]} \mathrm{In}$ present work, a trial has been made to develop mucoadhesive buccal film dosage for improving and enhancing the drug release in a controlled manner. Different grades of HPMC, which is biodegradable, were used in present study.

\section{MATERIALS AND METHODS}

Ivabradine hydrochloride was obtained as a gift sample from Unichem Pvt. Ltd, Mumbai, (Maharashtra) India. Hydroxyl propyl methylcellulose (HPMC K15M and K100M) was procured from Yarrow Chemicals Pvt. Ltd., India. All other reagents used were of analytical grade. The films were prepared by solvent casting method.

\section{Pre formulation studies}

Drug excipient compatibility studies by using fourier transform infrared spectroscopy

Pure Ivabradine HCl, HPMC K100 and K15 and Optimized formulation analyzed by FTIR for the drug-polymer interaction.

\section{Method (Solvent casting method)}

The films of respective composition, as shown in the Table 1, were devised using HPMC K15, HPMC K100 as polymers and carbopol (CP) 940 as bioadhesive polymer, polyethylene glycol (PEG) 6000 as a plasticizer, tween 80 as permeation enhancer, aspartame as sweetening and flavoring agents, along with drug and solvent. The solvent system used was 50:50 ratios of ethanol and chloroform. The drug was then dispersed uniformly in the viscous solution with continuous stirring on magnetic stirrer. In order to avoid entrapment of the air bubble inside the film, the entire drug-polymer-solvent system was subjected to sonication with ultrasonic bath sonicator. The solution was poured into moulds for casting and dried at (room temperature) for a period of $24 \mathrm{hrs}$. After drying the medicated patches of $2 \times 2 \mathrm{~cm}^{2}$ area were cut using a sterilized stainless steel scalpel, each film containing $5.0 \mathrm{mg}$ of drug.

\section{Characterization of buccal patches}

Physical appearance and surface texture

It includes visual inspection of patches and evaluation of texture by feel or touch. ${ }^{[6]}$

\section{Weight variation test}

From each formulation, five films of similar specifications have been chosen and subjected to weight variation test as per the IP procedure using Shimadzu digital balance. The average weight of five buccal films was subtracted from individual film weight. The mean \pm SD values were calculated for all the formulations. ${ }^{[6,7]}$

\section{Thickness variation test}

From each formulation, five films were chosen, and thickness was measured at different places with the help of screw gauge. The average film thickness and standard deviation were computed. ${ }^{[6,7]}$

\section{Surface pH study}

The surface $\mathrm{pH}$ of the patch was determined in order to investigate the possibility of any side effects, in vivo. A combined glass electrode was used for this purpose. The patches were allowed to swell by keeping it in contact with $1 \mathrm{ml}$ of distilled water ( $\mathrm{pH} 6.6 \pm 0.2$ ) for $15 \mathrm{~min}$ at room temperature, and $\mathrm{pH}$ was noted down by bringing the electrode in contact with the surface of the patch and allowing it to equilibrate for $1 \mathrm{~min} .^{[8]}$

\section{Content uniformity of film}

To ensure uniform distribution of Ivabradine in film, a content uniformity test was performed. The film was added to $100 \mathrm{ml}$ of phosphate buffer $\mathrm{pH} 6.6$ contained in a $250 \mathrm{ml}$ beaker, which was placed on temperature controlled magnetic stirrer maintained at $37^{\circ} \mathrm{C}$. The medium was stirred at $300 \mathrm{rpm}$ with a Teflon coated magnetic bead for $3 \mathrm{hrs}$. Then, the solution was filtered through $0.45 \mu \mathrm{m}$ membrane filter, and the filtrate was examined for the drug content at $286.0 \mathrm{~nm}$ using UV-Spectrophotometer. ${ }^{[6,7]}$

\section{Percentage moisture absorption and loss}

The percentage moisture absorption test was carried out to ensure physical stability or integrity of buccal films. Buccal films were weighed and placed in a desiccator containing $100 \mathrm{ml}$ of saturated solution of aluminum chloride, and $75 \pm 5 \% \mathrm{RH}$ was maintained. After three days, the buccal films were taken out and re-weighed. The percentage moisture absorption was calculated using the formula specified below. Buccal films were weighed and kept in a desiccator containing anhydrous calcium chloride. After three days, the patches were taken out and re-weighed. The percentage moisture loss was calculated using the formula. ${ }^{[9]}$

$\%$ Moistureabsorption $=\frac{\text { Final weight }- \text { Initial weight }}{\text { Initial weight }} \times 100$

\begin{tabular}{|c|c|c|c|c|c|c|c|}
\hline $\begin{array}{l}\text { Formulation } \\
\text { code }\end{array}$ & $\begin{array}{l}\text { HPMC K15 mg } \\
(\% w / v)\end{array}$ & $\begin{array}{l}\text { HPMC K100 mg } \\
(\% w / v)\end{array}$ & Carbopol $940 \mathrm{mg}$ & PEG $6000 \mathrm{mg}$ & Aspartame $\mathrm{mg}$ & Tween mg & $\begin{array}{c}\text { Drug } 805 \% \\
\text { w/v mg }\end{array}$ \\
\hline $\begin{array}{l}\text { F1 } \\
\text { F2 } \\
\text { F3 } \\
\text { F4 } \\
\text { F5 } \\
\text { F6 }\end{array}$ & $\begin{array}{c}28.12(6) \\
37.50(8) \\
46.87 \text { (10) } \\
- \\
- \\
-\end{array}$ & $\begin{array}{c}- \\
- \\
- \\
28.12(6) \\
37.50(8) \\
46.87(10)\end{array}$ & $\begin{array}{l}0.42 \\
0.42 \\
0.42 \\
0.42 \\
0.42 \\
0.42\end{array}$ & $\begin{array}{l}16.87 \\
16.87 \\
16.87 \\
16.87 \\
16.87 \\
16.87\end{array}$ & $\begin{array}{l}0.28 \\
0.28 \\
0.28 \\
0.28 \\
0.28 \\
0.28\end{array}$ & $\begin{array}{l}0.0023 \\
0.0023 \\
0.0023 \\
0.0023 \\
0.0023 \\
0.0023\end{array}$ & $\begin{array}{l}5 \\
5 \\
5 \\
5 \\
5 \\
5\end{array}$ \\
\hline
\end{tabular}

HPMC: Hydroxypropyl methyl cellulose 


$$
\% \text { Moisture loss }=\frac{\text { Initial weight-Final weight }}{\text { Initial weight }} \times 100
$$

\section{Swelling study}

The purpose of measuring swelling index is to determine the ability of hydrophilic polymers used in formulation to take up water upon hydration. The hydration and swelling behavior of the polymer was reported to be crucial for its bioadhesive character, because the former is necessary to initiate intimate contact of the film with the mucosal surface. The adhesion increases with the degree of hydration until a point where over hydration leads to an abrupt drop in adhesive strength due to disentanglement at the polymer tissue interface. The rate and the extent of film hydration and swelling also affect the film adhesion and consequently, the drug release from the film. The rate of swelling affects the duration of adhesion with faster swelling, resulting in adhesion of shorter duration. The present study revealed that excessive hydration (HPMC patches) can lead to a weakening of the adhesive bond due to dilution of functional groups responsible for the adhesive interaction between the bioadhesive film and mucosa. ${ }^{[9]}$

\section{Folding endurance}

Films did not show any cracks even after folding for more than 300 times. Hence, it was taken as the end-point. Folding endurance did not vary when the comparison was made between plain films and drug-loaded films. ${ }^{[6]}$ Folding endurance of the film was determined by repeatedly folding one film at the same place till it broke or folded up to 300 times manually, which was considered satisfactory to reveal good film properties. ${ }^{[10]}$

\section{In vitro drug release studies}

The patches containing Ivabradine were evaluated for in vitro release. As there was no official method prescribed for in vitro drug release study for buccal patches, a simple in-house laboratory assembly was utilized simulating the conditions of oral cavity. A buccal strip of $2 \times 2 \mathrm{~cm}^{2}$ (containing $5 \mathrm{mg}$ of drug) affixed with the membrane was held at the center of a microscope slide by means of cynoacrylate adhesive. The slide was placed at an angle of $45^{\circ}$ in a $150 \mathrm{ml}$ beaker containing $100 \mathrm{ml}$ of $\mathrm{pH} 6.6$ buffer preheated to $37^{\circ} \mathrm{C}$. The beaker was kept in water bath at $37^{\circ} \mathrm{C}$. A non-agitated system was selected to eliminate any effect of turbulence on the release rate to assure that no disruption of strip occurred. Periodically samples were withdrawn and assayed for drug content by spectrophotometrically at $286 \mathrm{~nm} .^{[11,12]}$

\section{Ex vivo studies}

The modified Franz diffusion cell was used for permeation studies. It consists of two compartments, one is donor compartment and another is receptor compartment of $25 \mathrm{ml}$ capacity. The receptor compartment was covered with water jacket to maintain temperature at $37^{\circ} \mathrm{C}$. The separated buccal epithelium was mounted between the chamber, and the receptor compartment was filled with $23 \mathrm{ml}$ of phosphate buffer of $\mathrm{pH}$ 6.6. A Teflon-coated magnetic bead was placed in the receptor compartment, and the whole assembly was placed on the magnetic stirrer, and buccal epithelium was allowed to stabilize for a while. After stabilization, samples of $1 \mathrm{ml}$ were withdrawn at regular intervals, suitably diluted, and were analyzed spectrophotometrically at $286 \mathrm{~nm} \cdot{ }^{[13,14]}$

\section{Kinetic modeling}

In order to understand the kinetic and mechanism of drug release, the result of in vitro drug release study of buccal patches were fitted with various kinetic equation like zero order (equation 1) cumulative percentage release Vs. time, Higuchi's model (equation 2) as cumulative \% drug release Vs. square root of time. ' $r$ ' and ' $k$ ' values were calculated for the linear curve obtained by regression analysis of the above plots.

$\mathrm{C}=\mathrm{k}_{0} \mathrm{t} \ldots \ldots \ldots \ldots$

Where $\mathrm{k}_{0}$ is the zero order rate constant expressed in units of concentration/time, and $\mathrm{t}$ is time in $\mathrm{h}$.

$\mathrm{Q}=\mathrm{k}_{\mathrm{H}} \mathrm{t}^{1 / 2} \cdots \cdots \cdots \cdots$

Where, $\mathrm{k}_{\mathrm{H}}$ is Higuchi's square root of time kinetic drug release constant.

To understand the release mechanism in vitro, data was analyzed by Peppas model (equation 3 ) as log cumulative drug release Vs. log time, and the exponent ' $n$ ' was calculated through the slope of the straight line.

$\mathrm{M}_{\mathrm{t}} / \mathrm{M}_{\infty}=\mathrm{bt}^{\mathrm{n}} \ldots \ldots \ldots \ldots$

Where ' $M_{t}$ ' is amount of drug release at time $t, M_{\infty}$ is the overall amount of the drug, $\mathrm{b}$ is constant, and $\mathrm{n}$ is the release exponent indicative of the drug release mechanism. If the exponent ' $n$ ' $=0.5$ or near, then the drug release mechanism is Fickian diffusion, and if ' $n$ ' have value near 1.0, then it is non-Fickian diffusion. The in vitro release data was fitted to various kinetic models like Higuchi, First order, Zero order, and Korsemeyer - Peppas.

\section{Ex vivo bioadhesive strength}

Fresh goat buccal mucosa was obtained from a local slaughter house, placed in saline, and used within 2 hrs of slaughter. The mucosal membrane was cleaned and separated by removing the underlying fat and loose tissues. Bioadhesive strength of the patch was measured on a modified physical balance. The device was mainly composed of a two-arm balance. The left arm of the balance was replaced by a small plastic cap vertically suspended through a wire. At the same side, a movable platform was maintained in the bottom in order to fix the model mucosal membrane. ${ }^{[9,12]}$ The goat buccal mucosa was cut into pieces and washed with phosphate buffer $\mathrm{pH}$ 6.6. A piece of buccal mucosa was tied to the open mouth of a diffusion cell, which was placed and tightly fitted in the center of glass beaker. The phosphate buffer $\left(\mathrm{pH} 6.6,37 \pm 2^{\circ} \mathrm{C}\right.$ ) was filled in to the glass beaker in such a way that it makes contact with buccal mucosal surface. The 
patch was stuck to the lower side of flat surface plastic cap with cyanoacrylate adhesive. Two pans of the balance were balanced with $5 \mathrm{~g}$ weight on the right hand side pan. A weight of $5 \mathrm{~g}$ was removed from the right hand side pan, which lowered the pan along with the patch over the mucosa. The balance was kept in this position for 5 min contact time, and then slowly the weights were increased on the right hand side pan till the patch separated from the mucosal surface ${ }^{[10,11]}$ as shown in the Figures 1-3. ${ }^{[15]}$

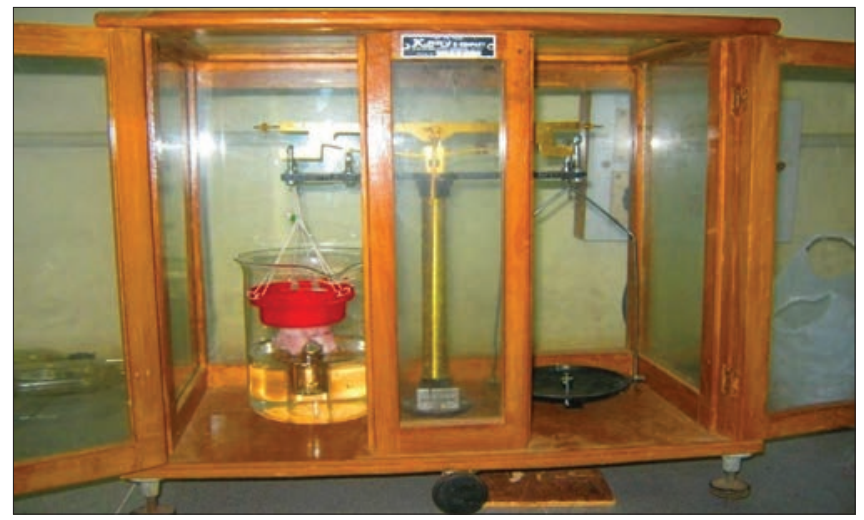

Figure 1: Experimental set up for bioadhesive strength

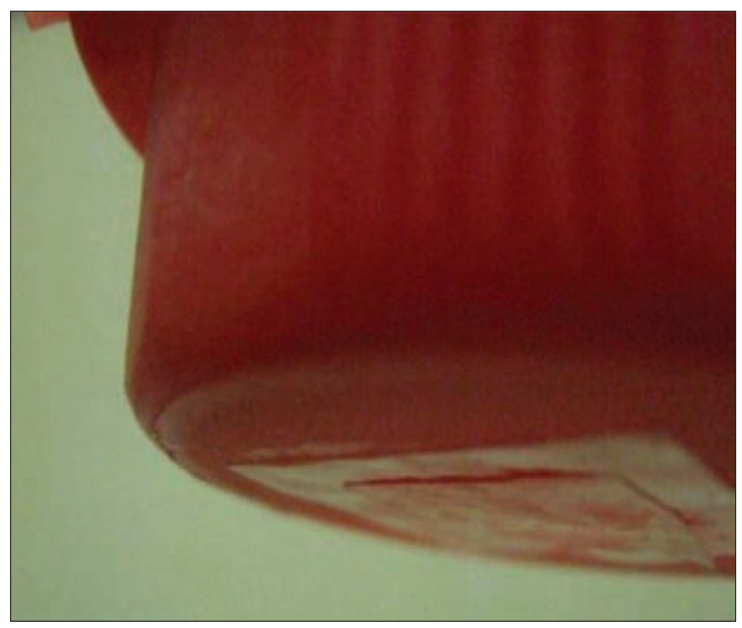

Figure 2: Patch adhered to the cap

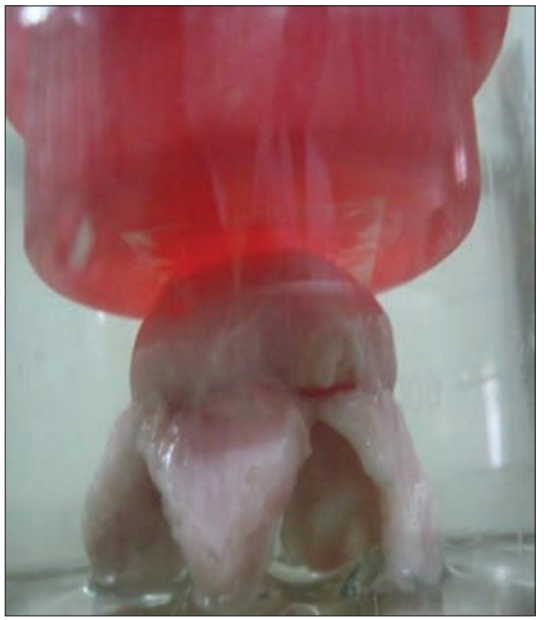

Figure 3: Patch adhered to mucosa

\section{Stability study}

The stability study of patches was performed at laboratory in human saliva were collected from 20 humans ages between 20 and 35 years and filtered. The films were placed in separate petri dishes containing $5 \mathrm{ml}$ of human saliva and were put in an oven at $37^{\circ} \mathrm{C} \pm 0.2^{\circ} \mathrm{C}$ for $6 \mathrm{hrs}$. At regular time intervals, films were examined for changes in color, shape, collapse, and physical stability. ${ }^{[16-17]}$

\section{RESULTS AND DISCUSSION}

The present study was undertaken to design, formulate, and evaluate Ivabradine hydrochloride for sustained release dosage form. IR study indicated good compatibility between drug, polymer, and excipients as there was neither shift in the principal peaks nor presence or absence of any principal peaks of the drug/ polymer. The formulations were evaluated for various parameters, and the results obtained were within the range.

Pre formulation studies

The obtained results indicated that there was no positive evidence for the interaction between drug and the utilized buccoadhesive material. These results indicated the compatibility of the polymers (HPMC, PEG, carbopol) for preparation of mucoadhesive buccal films of Ivabradine hydrochloride, as shown in Table $2 \mathrm{a}, \mathrm{b}$, and c.

\section{Table 2a: IR spectral values of Ivabradine $\mathrm{HCl}$ (Pure drug)}

\begin{tabular}{lcccc}
\hline \multicolumn{5}{c}{ Peaks of functional groups $\left(\mathbf{c m}^{-1}\right)$} \\
\hline Aliphatic & Alkanes & Aromatic & Aromatic & Alkenes \\
C-N & $\begin{array}{c}\text { C }=\mathbf{C} \\
\text { stretch }\end{array}$ & $\begin{array}{c}\text { C-C } \\
\text { stretch }\end{array}$ & $\begin{array}{c}\text { C-H } \\
\text { stretch }\end{array}$ & $\begin{array}{l}\text { R- }-\mathbf{C H}_{2} \mathbf{C H}_{3} \\
\text { stretch }\end{array}$ \\
\hline 2940.91 & 1105 & 1633 & 1469 & 3476.47 \\
\hline
\end{tabular}

IR : Infra Red Spectroscopy, HCL: Hydrochloride

Table 2b: IR spectral values of hydroxypropyl methyl cellulose K15 and hydroxypropyl methyl cellulose K100

\begin{tabular}{lc}
\hline \multicolumn{2}{c}{ Peaks of functional groups $\left.\mathbf{( c m}^{-1}\right)$} \\
\hline Asymmetrical C-O-C stretch & Aromatic C-H stretch \\
\hline (K15) 1201 & 3562.84 \\
(K100) 1215 & 3562.84 \\
\hline R: Infra red spectroscopy
\end{tabular}

Table 2c: IR spectral values of optimized formulations (F2 and F5)

\begin{tabular}{|c|c|c|c|c|c|}
\hline \multicolumn{6}{|c|}{ Peaks of functional groups $\left(\mathrm{cm}^{-1}\right)$} \\
\hline Polymer & 5 Aliphatic & Alkenes & Aromatic & Aromatic & Alkanes \\
\hline & $\begin{array}{c}\text { C-N } \\
\text { stretch }\end{array}$ & $\begin{array}{c}\mathrm{C}=\mathrm{C} \\
\text { stretch }\end{array}$ & $\begin{array}{c}\text { C-C } \\
\text { stretch }\end{array}$ & $\begin{array}{c}\text { C-H } \\
\text { stretch }\end{array}$ & $\mathrm{R}-\mathrm{CH}_{2} \mathrm{CH}$ \\
\hline $\begin{array}{l}(\mathrm{K} 15) \\
(\mathrm{K} 100)\end{array}$ & $\begin{array}{l}1107.55 \\
1106.73\end{array}$ & $\begin{array}{l}1631.48 \\
1632.52\end{array}$ & $\begin{array}{l}1466.6 \\
1466.6\end{array}$ & $\begin{array}{c}3475.24 \\
3476.7\end{array}$ & $\begin{array}{l}2942.09 \\
2946.92\end{array}$ \\
\hline
\end{tabular}


Lodhi, et al.: Formulation and evaluation of buccal film of Ivabradine Hydrochloride

\begin{tabular}{|c|c|c|c|c|c|c|}
\hline \multirow[t]{2}{*}{ Formulation code } & \multirow[t]{2}{*}{ Weight (mg) } & \multirow[t]{2}{*}{ Thickness (mm) } & \multirow[t]{2}{*}{ Surface Ph } & \multirow[t]{2}{*}{ Content uniformity } & \multicolumn{2}{|c|}{$\%$ Moisture } \\
\hline & & & & & Absorption & Loss \\
\hline F1 & $33.50+1.323$ & $0.113+0.015$ & $6.93+0.152$ & $94.93+0.393$ & 5.23 & 4. \\
\hline F2 & $39.16+0.763$ & $0.130+0.01$ & $6.10+0.721$ & $94.40+0.697$ & 6.11 & 5.3 \\
\hline F3 & $44.33+3.81$ & $0.163+0.015$ & $5.70+0.173$ & $96.02+2.215$ & 6.98 & 5.21 \\
\hline F4 & $45.93+3.18$ & $0.123+0.025$ & $6.50+1.73$ & $93.20+1.375$ & 6.20 & 5.34 \\
\hline F5 & $62.90+0.79$ & $0.173+0.015$ & $6.43+0.257$ & $94.13+1.514$ & 7.40 & 5.14 \\
\hline F6 & $67.26+2.05$ & $0.216+0.035$ & $6.36+0.404$ & $96.44+0.580$ & 8.10 & 5.36 \\
\hline
\end{tabular}

\begin{tabular}{|c|c|c|c|c|}
\hline $\begin{array}{l}\text { Formulation } \\
\text { code }\end{array}$ & $\begin{array}{c}\text { Percentage } \\
5\end{array}$ & $\begin{array}{c}\text { Swelling } \\
10\end{array}$ & $\begin{array}{c}\text { index in } \\
\text { time } 30\end{array}$ & $(\min ) 60$ \\
\hline $\begin{array}{l}\text { F2 } \\
\text { F5 }\end{array}$ & $\begin{array}{l}4.9 \\
5.2\end{array}$ & $\begin{array}{l}6.4 \\
9.4\end{array}$ & $\begin{array}{l}16.8 \\
21.2\end{array}$ & $\begin{array}{l}25.2 \\
33.5\end{array}$ \\
\hline
\end{tabular}

\begin{tabular}{lr}
$\begin{array}{l}\text { Table 4: Drug release parameters of various } \\
\text { formulations }\end{array}$ \\
\hline Drug release studies & $\begin{array}{r}\text { Percentage drug release } \\
\text { at the end of } \mathbf{6}^{\text {th }} \mathbf{h}\end{array}$ \\
\hline In vitro drug release study & \\
FI & $95.15(5 \mathrm{~h})$ \\
F2 & $97.61(6 \mathrm{~h})$ \\
F3 & $97.25(5 \mathrm{~h})$ \\
F4 & $94.16(5 \mathrm{~h})$ \\
F5 & $98.37(6 \mathrm{~h})$ \\
F6 & $90.36(5 \mathrm{~h})$ \\
F2 vivo buccal permeation study & \\
F5 & $66.85(6 \mathrm{~h})$ \\
\hline
\end{tabular}

Table 5: Ex vivo bio-adhesive strength of
optimized formulations (F2 and F5)
\begin{tabular}{lc} 
Formulation code & Ex vivo strength (MS) (mean \pm SD) \\
\hline F2 & $4.52 \pm 0.48$ \\
F5 & $6.10 \pm 0.40$ \\
\hline
\end{tabular}

Characterization of buccal patches

Physical appearance and surface texture of patches

Patches were checked with visual inspection and by feel or touch. The observation suggests that the patches are having smooth surface, and the feature was elegant enough.

\section{Weight variation test}

Patches prepared with different concentrations of HPMC $\mathrm{K} 15(6 \%, 8 \%$, and $10 \%)$, weighed about $32.5 \pm 1.323,39.16 \pm 0.763$, and $44.33 \pm 3.81 \mathrm{mg}$, respectively. The patches prepared with different concentrations of HPMC K100 (6\%, 8\%, and 10\%) weighed about $45.98 \pm 3.18,62.9 \pm 0.79$, and $67.26 \pm 2.05 \mathrm{mg}$, respectively, as shown in the Table $3 \mathrm{a}$.

\section{Thickness variation test}

The thickness was found to be $0.113 \pm 0.015,0.130 \pm 0.01$, $0.163 \pm 0.015 \mathrm{~mm}$, respectively, for patches prepared with different concentrations of HPMC K15 (6\%, 8\%, and 10\% w/v) polymers. Similarly, patches prepared with different concentrations of HPMC $\mathrm{K} 100(6 \%, 8 \%$, and $10 \% \mathrm{w} / \mathrm{v})$ polymer, the thickness was found to be
$0.123 \pm 0.025,0.17333 \pm 0.015$, and $0.216 \pm 0.035 \mathrm{~mm}$, respectively. In all the cases, the calculated standard deviation values were found to be very low and suggested that the prepared patches were uniform in thickness within the batches, as shown in the Table 3a.

\section{Surface $\mathrm{pH}$ study}

Surface $\mathrm{pH}$ of the patches was determined by keeping in contact with $1 \mathrm{ml}$ of distilled water. The surface $\mathrm{pH}$ was noted by bringing a combined glass electrode or $\mathrm{pH}$ paper near the surface of patches and allowing equilibrating for $1 \mathrm{~min}$, and the average surface $\mathrm{pH}$ of all patches was given in Table 3 . The standard deviation values calculated for all the patches are very low, which suggested that the surface $\mathrm{pH}$ of all the patches within the batches was found to be uniform as shown in the Table $3 a$.

\section{Content uniformity of film}

The results of content uniformity tests indicated that the drug was uniformly dispersed as shown in the Table 3a. Recovery was possible to the tune of $93.02 \%$ to $96.44 \%$. All the formulations showed more than $94 \%$ of the drug loading, indicating much of the drug is not lost.

\section{Percentage moisture absorption and loss}

Data reveals that patches contain water-insoluble polymer carbopol and, therefore, the percentage moisture loss is least as shown in the Table 3a. However, water-soluble patches (HPMC patches) exhibited more absorption of moisture.

\section{Swelling study}

The swelling index of the patches was determined by immersing pre-weighed patch of size $2 \times 2 \mathrm{~cm}^{2}$ in $50 \mathrm{ml}$ water. The strips were taken out carefully at 5, 10,30, and $60 \mathrm{~min}$ intervals, blotted with filter paper, and weighed accurately; the average swelling index of all patches was given in Table $3 \mathrm{~b}$.

\section{Folding endurance}

The folding endurance was found to be greater than 300 times in case of all the formulations. This makes the system acceptable for movement of mouth, indicating good strength and elasticity. Folding endurance test results indicated that the films would maintain the integrity with buccal mucosa when applied.

\section{In vitro drug release studies}

Phosphate buffer $\mathrm{pH}$ 6.6 was used as medium for the release study of Ivabradine hydrochloride patches containing different ratios of polymer to drug as it is shown in the Table 1. It is apparent from the plots Figure 4 that the drug release was governed by polymer 
content. An increase in the polymer content was associated with decrease in drug release rates. The patch $(\mathrm{F} 1)$ released the drug much faster than the other formulations. This is because the polymer HPMC K15 used was of lesser viscosity and unlike the other grade of polymer, HPMC K100 dissolves much faster. Formulations with HPMC K100 polymer content (F4, F5, and F6) showed slower drug release as it is given in Table 4 and Figure 4. Increasing the amount of the polymer in the patches produced the water-swollen gel-like state that could substantially reduce the penetration of the dissolution medium into the patches, and so the drug release was retarded.

\section{Ex vĩvo permeation}

Ex vivo permeation of buccal films of Ivabradine hydrochloride was evaluated using porcine buccal membrane. The results of drug permeation from buccal patches of Ivabradine hydrochloride revealed that drug was released from the formulation and permeated through the porcine buccal membrane, hence they can possibly permeate through the human buccal membrane. The results indicated that the drug permeation was more in F2 and F5 formulations of Ivabradine hydrochloride as shown in Table 4 and Figure 5.

\section{Kinetic assessments}

In buccal patch, all the formulations follow Zero order, First order, Higuchi and Korsemeyer - Peppas models. When the data were plotted according to the zero order equation, the formulations

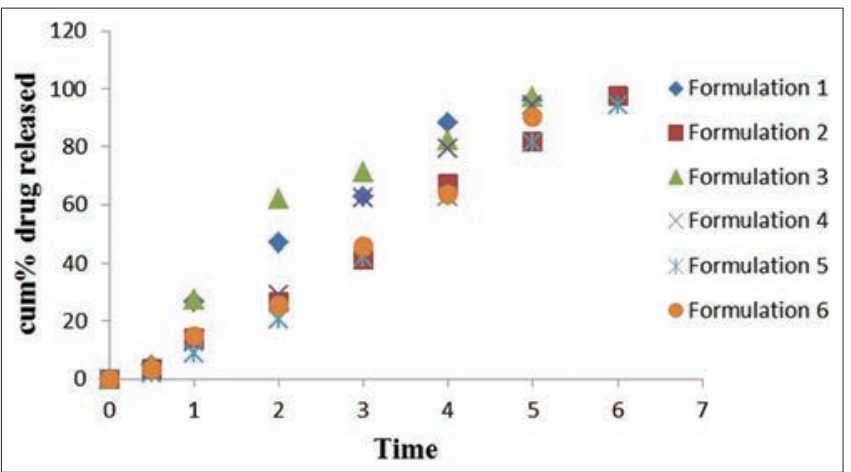

Figure 4: In vitro drug release studies

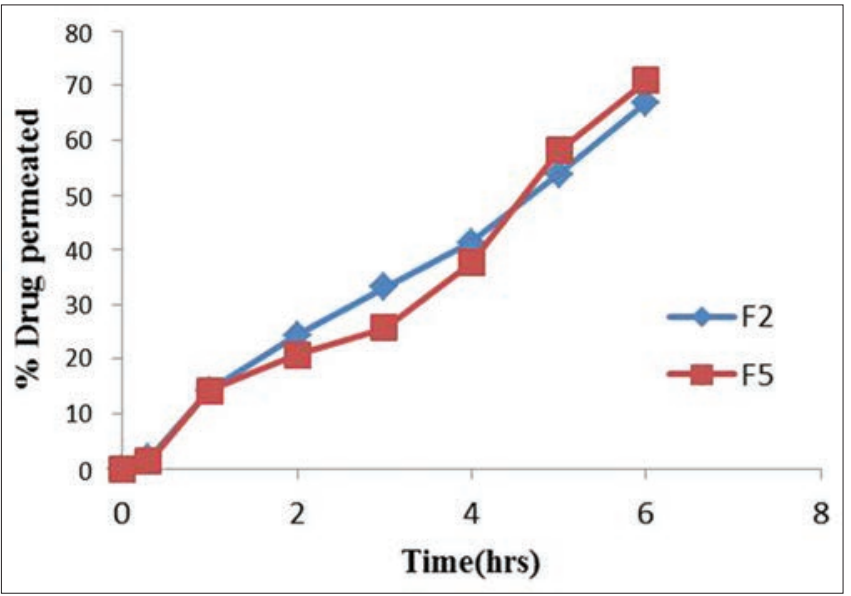

Figure 5: Ex vivo permeation showed a comparatively poor linearity, with regression value in range between 0.9754 and 0.9925 , whereas the regression value for first order equation was found between 0.8322 and 0.9211 , and the regression value for Higuchi was found between 0.9132 and 0.9924 , which indicated that drug release from optimized formulation (F2 and F5) was independent of drug concentration. In buccal patch, the " $n$ " value for Peppas model was found to be ' $n$ ' $>0.89$, (1.08 and 1.35 for best formulation), which indicates that the drug released from the formulation by Super case II mechanism.

\section{EX vivo bioadhesive strength}

The bioadhesive force (in $\mathrm{kg} / \mathrm{m} / \mathrm{s}^{2}$ ) for the different formulations was found as per the procedure given in methodology, and the results are shown in Table 5. The increase in mucoadhesiveness may be due to the formation of a strong gel by the formation of hydrogen bonding or other types of bonding by the hydrophilic polymer HPMC and CP, which interpenetrates intensely into the mucin molecules. The concentration of PEG 6000 did not have much effect on the bioadhesion of the patch.

\section{Stability study}

The stability study of the optimized buccal patches (F2 and F5) was performed in natural human saliva. The buccal patches did not show any significant changes in their color, shape, and physical texture.

\section{CONCLUSION}

In the present study, buccal patches of Ivabradine hydrochloride were prepared by solvent casting method employing polymer such as HPMC K15M and HPMC K100M along with carbopol 940 in different combinations. F2 and F5 were selected as optimized formulations. The optimized batch showed maximum in vitro drug release (97.61\% and 98.37) and followed zero-order model of drug release and fairly good amount of drug permeation through the membrane in 6 hrs and shows satisfactory physical stability. The present study indicated enormous potential of mucoadhesive buccal patches containing Ivabradine for systemic delivery with an added advantage of circumventing hepatic first pass metabolism. Further work is recommended to support its efficacy claims by long-term pharmacokinetic and pharmacodynamic studies in human beings.

\section{ACKNOWLEDGEMENT}

The authors wish to acknowledge the Shree Devi College of Pharmacy, Mangalore (Karnataka) India, for providing the necessary facilities and financial support to carry out this project. The authors are also thankful to Unichem Pvt. Ltd., Mumbai (Maharashtra) India for providing the free gift sample of drug Ivabradine hydrochloride.

\section{REFERENCES}

1. Padma VD, Manisha $\mathrm{HH}$. Oral transmucosal drug delivery. In: Jain NK, editor. Controlled and novel drug delivery. $1^{\text {st }}$ ed. 
New Delhi: CBS Publishers; 2004. p. 52-81.

2. Mutalik S, Udupa N. Formulation development, in vitro and in vivo evaluation of membrane controlled transdermal systems of glibenclamide. J Pharm Pharm Sci 2005;8:26-38.

3. Chein YW. Novel drug delivery system. $2^{\text {nd }}$ ed. New York: Marcel Dekker, Inc.; 1992. p. 50: 197-28, 353-80, 456-57.

4. Anya $\mathrm{H}$, Andrew L. Drug delivery and targeting. $1^{\text {st }}$ ed. London and New York: Taylor and Francis Inc; 2001. p. 168-69.

5. Verma S, Kaul M, Rawat A, Saini S. An overview on buccal drug delivery system. Int J Pharm Sci Res 2011; 6:1303-21.

6. Alagusundaram M, Chengaiah B, Ramkanth S, Angala PS, Chetty $M$, Dhachinamoorty. Formulation and evaluation of mucoadhesive buccal films of ranitidine. Int J Pharmtech Res 2009;1:557-63.

7. Indian pharmacopoeia published by the controller of Publication. New Delhi: 2007. Vol. I. p. 241-2.

8. Indira PR, Uma Sankari K. Design, evaluation and in vitro - in vivo correlation of glibenclamide bucco-adhesive films. Int J Pharm Invest 2012;2:26-33.

9. Pankil GA, Patel MR, Patel KR, Patel NM. A review article on mucoadhesive buccal drug delivery system. IntJ Pharm Sci Res Dev 2011;5:159-73.

10. Semalty M, Semalty A, Kumar G. Formulation and characterization of mucoadhesive buccal films of glipizide. Indian J Pharm Sci 2008;70:43-8.

11. Khanna R, Agarwal SP and AhujaA. Preparation and evaluation of mucoadhesive buccal films of clotrimazole for oral candida infection. Indian J Pharm Sci 1997;59:299-305.

12. Purohit K, Jangid MK, John AS, Shivanand K. Formulation and evaluation of Timolol maleate buccal mucoadhesive patches. J Pharm Res 2010;8:2031-5.

13. Singhal $P$, Jadoun GS, Sinha M, Saraf SA. Formulation and evaluation of buccal patches of terbutaline sulphate. Int J Res Pharm Sci 2010;4:440-9.

14. Deshmane SV, Channawar MA, Chandewar AV, Joshi UM, Biyani KR. Chitosan based sustained release mucoadhesive buccal patches containing verapamil $\mathrm{HCl}$. Int J Pharm Pharm Sci 2009;1:216-29.

15. Nafee NA, Ismail FA, Boraie NA, Mortad LM. Mucoadhesive buccal patches of miconazle nitrate: In vitro/in vivo performance and effect of ageing. Int J Pharm 2003;264:1-14.

16. Patel VM, Prajapati BG, Patel MM. Effect of hydrophilic polymers on buccoadhesive eudragit patches of propanolol hydrochloride using factorial design. AAPS PharmSciTech 2007;8:E1-8.

17. Costa P, Sousa lobo JM. Modeling and comparison of dissolution profiles. Eur J Pharm Sci 2001;13:123-33.

How to cite this article: Lodhi M, Dubey A, Narayan R, Prabhu $P$, Priya S. Formulation and evaluation of buccal film of Ivabradine hydrochloride for the treatment of stable angina pectoris. Int J Pharma Investig 2013;3:47-53.

Source of Support: Nil. Conflict of Interest: None declared.

\section{Author Help: Reference checking facility}

The manuscript system (www.journalonweb.com) allows the authors to check and verify the accuracy and style of references. The tool checks the references with PubMed as per a predefined style. Authors are encouraged to use this facility, before submitting articles to the journal.

- The style as well as bibliographic elements should be $100 \%$ accurate, to help get the references verified from the system. Even a single spelling error or addition of issue number/month of publication will lead to an error when verifying the reference.

- $\quad$ Example of a correct style Sheahan P, O'leary G, Lee G, Fitzgibbon J. Cystic cervical metastases: Incidence and diagnosis using fine needle aspiration biopsy. Otolaryngol Head Neck Surg 2002;127:294-8.

- Only the references from journals indexed in PubMed will be checked.

- $\quad$ Enter each reference in new line, without a serial number.

- $\quad$ Add up to a maximum of 15 references at a time.

- If the reference is correct for its bibliographic elements and punctuations, it will be shown as CORRECT and a link to the correct article in PubMed will be given.

- If any of the bibliographic elements are missing, incorrect or extra (such as issue number), it will be shown as INCORRECT and link to possible articles in PubMed will be given. 